\title{
Internal Auditor Transformation Strategy in the Industrial Revolution 4.0 Era: Literature Review
}

\author{
Rini Rosa ${ }^{1}$, Sri Rahayu ${ }^{2}$, Yudi $^{3}$, Muhammad Gowon $^{4}$ \\ \{rinirosajambi@gmai1 ${ }^{1}$,srijambi@gmail.com², yudi.telanai@gmail.com ${ }^{3}$,gowonjambi@gmailcom ${ }^{4}$ \} \\ Student of Doctoral Program in Economics, Universitas Jambi, Jl. Jambi-Ma. Bulian Km.15 \\ Mendalo Darat Jambi ${ }^{1}$, Accouting Department, Universitas Jambi, Jl. Jambi-Ma. Bulian Km. \\ 15 Mendalo Darat Jambi ${ }^{2,3,4}$
}

\begin{abstract}
This paper is intended to identify a transformation strategy that can be applied by the Government Internal Supervisory Apparatus (APIP) to face audit challenges in the industrial revolution 4.0 era. In line with the influence of industry 4.0 on audit activities, APIP must quickly adapt to technological developments. Utilization of technology 4.0 places APIP as a business analyst to find errors in business processes and determine solutions to these errors. So, in order to face the challenges of industry 4.0, an APIP transformation strategy is needed. The author reveals that the APIP transformation strategy in facing industry 4.0 such as (1) APIP must be able to use data collecting equipment, such as sensors and software, to collect data, (2) APIP must have characters that can be their hallmark in completing their audit tasks. These characters include cognitive abilities, ability to solve complex problems, communication skills, understanding of their position in the internal control system, and agility (3) APIP must be professional, millennial, innovative, and not afraid of failure while still prioritizing integrity, objectivity, and professionalism.
\end{abstract}

Keywords: APIP; Industry 4.0; Transformation Strategy

\section{Introduction}

Industrial 4.0 has gained worldwide attention and became one of the phenomena that are vital at this time. All countries are preparing to face the industrial revolution, in which the industrial revolution has touched all lines of life, including the economic sector and governance. Schwab [1] describes the stages of development of the industrial revolution, starting from industry 1.0 to industry 4.0 , namely:

1. Industrial Revolution 1.0 (1750-1870): utilizing water and steam power to mechanize production.

2. Industrial Revolution 2.0 (the $1870 \mathrm{~s}$ ): utilizing electric power for mass production.

3. Industrial Revolution 3.0 (The early 1970s): focused on the use of information technology and electricity for production automation.

4. Industrial Revolution 4.0 (after 2015) combines more complex cyber, physical, and biological systems. 
Industry 4.0 also affects the entire scope of accounting work in the fields of taxation, financial accounting, management accounting, auditing, internal control, risk management, corporate governance, and other accounting work areas, experiencing changes in both business processes and related work systems, recently. Automation and digitization have impacted almost the entire scope of accounting work, especially financial accounting. Digitization has also replaced many functions in the accounting workspace.

Report of the World Economic Forum [2] in The Future of Jobs Report suggests that accounting jobs are expected to decline $26 \%$ in 2022 due to automation and the development of the 4.0 industry. However, as a profession, accountants and auditors are faced with the next challenge that is more focused on advanced analytical skills supported by Industry 4.0. Such as big data analytics, the internet of things, and artificial intelligence allow accountants or auditors to take steps to detect, prevent, and prescriptive.

Industry 4.0 impacts government governance, particularly the role of internal government auditors, often known as APIP. APIP's role is becoming increasingly critical due to the impact of Industry 4.0 on the system and dynamics of APIP's audit activities. APIP performs internal control operations on the performance of an organization's responsibilities and functions and supervision in the form of reviews, audits, evaluations, and monitoring, among other activities [3]. APIP must be able to adapt to the impact of industry 4.0 for APIP audit activities. APIP is also required to be able to carry out its functions effectively amid the challenges and risks of the current disruptive era.

One of the things that APIP must anticipate is the increase in digitization that allows all data to be in cyber/online systems. It is reinforced by the results of previous studies, which prove that the auditing profession is undergoing a shift as a more digital organization, so the changes that will occur in the auditor profession are unavoidable [4]-[8]. Risks in the context of security and data accuracy become a challenge in digitization compared to data obtained manually. Government Internal Auditors at Conference organized by the Ministry of Finance [9] stated that according to the direction of the President, at a minimum of $85 \%$ in 2019 , APIPs (Ministry / Agency, Region) have obtained the title level 3 (integrated). It is also considered one of the government's efforts in dealing with the dynamics of 4.0 and the disruptive effects that occur.

The Institute of Internal Auditors [10] suggests five things that auditors can do in dealing with this disruptive era, such as focusing on assurance, involving experts in their fields, investing in training and disruptive technology, utilizing the latest technology, and anticipating risks that may occur during audit activity. By doing preparatory and preventive measures in welcoming Industry 4.0, APIPs are expected to work more effectively and maximize the benefits and minimize the risk of Industry 4.0 negatives that may occur to achieve accountability and clean governance.

Professionally, the Indonesian Institute of Accountants (IAI) has recently formulated Program Prakarsa 6.1 [11], which states: When the business model and the economy are transformed in such a way, there is no guarantee that a profession will survive and be relevant in the future. Every profession must do something that keeps it afloat in the vortex of digital economic activity. Thus, APIP must innovate and adapt as soon as possible to welcome Industry 4.0 and anticipate disruptive risks to its profession, otherwise take opportunities and maximize IT developments. Therefore, they can contribute effectively to provide added value to institutions to support the performance improvement and a better good \& clean governance.

To accelerate the improvement of the quality of government management, the government has specifically listed the improvement of APIP capabilities as a target on the 2015 to 2019 development plan [12]. The Internal Audit Capability Model (IACM) divides APIP 
capabilities into 5 (five) levels: initial (level 1), infrastructure (level 2), integrated (level 3), managed (level 4), and optimized (level 5). At each level of capability, it consists of 6 (six) elements, namely: 1) role and service elements, (2) HR management elements, (3) professional practice elements, (4) performance management and accountability elements, (5) elements relationships and organizational culture and, (6) governance structure elements [13].

The IACM level can help an organization assess the competencies possessed by APIP and, as a guide for APIP, to increase the capability of its organization so that it can move up to the next level. The IACM level also provides an overview to the government regarding the obstacles and challenges in implementing good and efficient government management.

The SPIP (Government Agency Control System) Maturity Level can indicate the auditee's readiness in each agency as defined in the level of achievement. This includes level 0 , which is not yet available, level 1 is pioneering, level 2 is developing, level 3 is defined, level 4 is managed and measurable, and level 5 is optimum. Table of development of APIP Capabilities and SPIP Maturities for the last 2 (two) years is below:

Table 1. Results of APIP Capability and Maturity of Government SPIP in Jambi Province in 2018 and 2019

\begin{tabular}{clcccc}
\hline \multirow{2}{*}{ Number } & \multicolumn{1}{c}{ Government } & \multicolumn{2}{c}{ SPIP Maturity } & \multicolumn{2}{c}{ APIP Capability } \\
\cline { 3 - 5 } & & $\mathbf{2 0 1 8}$ & $\mathbf{2 0 1 9}$ & $\mathbf{2 0 1 8}$ & $\mathbf{2 0 1 9}$ \\
\hline 1 & Jambi Province & 2 & 3 & 2 & 3 \\
2 & Jambi City & 2 & 3 & 2 & 3 \\
3 & Sungai Penuh City & 2 & 3 & 2 & 2 \\
4 & Sarolangun Regency & 2 & 2 & 2 & 2 \\
5 & Muaro Jambi Regency & 2 & 2 & 2 & 2 \\
6 & Tanjung Jabung Timur Regency & 2 & 2 & 2 & 2 \\
7 & Tanjung Jabung Barat Regency & 2 & 2 & 2 & 2 \\
8 & Kerinci Regency & 2 & 2 & 2 & 2 \\
9 & Merangin Regency & 2 & 2 & 2 & 2 \\
10 & Tebo Regency & 2 & 2 & 2 & 2 \\
11 & Muaro Bungo Regency & 2 & 3 & 2 & 3 \\
12 & Batang Hari Regency & 2 & 3 & 2 & 3 \\
\hline \multicolumn{7}{c}{ Source: $[14]$} & & &
\end{tabular}

Shown in table 1 above that from 2018 until 2019, only 5 Local Government on target maturity SPIP on RPJMN 2019 are Jambi, Jambi City, Sungai Penuh City, Muaro Bungo, and Batanghari Regency, while seven other Regional Governments do not reach the RPJMN target, or in other words, there is no increase in SPIP maturity. SPIP maturity level is a working guideline consisting of basic characteristics, where these basic characteristics indicate the maturity level of an organization in implementing SPIP. So, it can be concluded that most of the SPIP assessments in the regencies/cities in Jambi Province have not yet reached the maturity stage that was already set, so it is still considered insufficient to start the development that has a good effect on the economic growth in Jambi Province.

In table 1 it can also be seen that only four regional governments (Jambi Province, Jambi City, Muaro Bungo Regency, and Batanghari Regency) have reached APIP Level 3 capability level. In comparison, eight other Regional Governments have not. It is certainly feared to have an adverse impact on the ability of the supervisory apparatus to initiate the development of government affairs in the Regency/City Government in Jambi Province.

The conditions mentioned above are very worrying. The unpreparedness of the auditors and auditees has bad implications for the supervision process, so that it is feared that they will not be able to provide relevant information according to the purpose of the examination itself. 
The role of a good internal auditor can support the achievement of good governance of government organizations [15]. The very high gap in the audit era, according to the demands of the current era, has led to a slow process of supervising a task that can have implications for reducing public confidence in the auditors' role. This article tries to reveal how APIP must transform through innovation and adaptation as soon as possible to welcome Industry 4.0 to anticipate disruptive risks to its profession.

\section{Result and Discussion}

Auditing must adapt to the new environment as the industry progresses to the next generation. Based on the types of tools used in carrying out the audit process, audits are classified into 4 (four) generations [16]. These stages are described in the audit generation in the following table:

\begin{tabular}{cccc}
\multicolumn{4}{c}{ Table 2: Audit Generation } \\
\hline Audit 1.0 & Audit 2.0 & Audit 3.0 & Audit 4.0 \\
\hline Manual audit, & IT Audit & Inclusion of Big Data in & Semi and progressive \\
Tools: Pencil, & Tools: Excel, & audit analysis & automation of audits \\
Calculator & CAAT Software & Tools: Analytical Apps & Tools: Sensors, CPS, IoT/IoS, \\
& & & RFID, GPS \\
\hline
\end{tabular}

\subsection{Audit Evolution: From 1.0 to 4.0}

Traditional manual Auditing (Audit 1.0) has existed for millennia and provides a number of needs. Despite the fact that IT auditing (Audit 2.0) first appeared in the 1970s, most businesses today are computer-based. The lack of quality tools that allow conventional auditors (i.e., those without IT and analytics training) to manage functions that they currently undertake manually [17] could be attributed in part to the profession's conservatism and rigidity, as well as the categorization effect of increasingly obsolete restrictions [18]. Table 2 lists the major characteristics of this audit generation.

It may be stated that Audit 3.0 will arrive significantly quicker than the prior generation because new Big Data platforms could not be secured with previous technologies. Anachronistic laws, in which samples from 70 transactions are used to assess a population of millions of transactions, might cause delays, reducing the value of external guarantees.

\subsection{Audit Element 4.0}

Audit 4.0 will revolutionize the auditing profession by automating present operations, expanding their range, reducing times, and eventually boosting overall assurance quality. The effect of Audit 4.0 on the auditing profession is discussed in this section from four perspectives: standards, principles, technology, and auditors.

\subsection{Standard}

Vasarhelyi [19] highlights the formalization of auditing standards because most standards should be included in the software. After all, computer implementation is common in modern systems. In conclusion, the ambiguity in existing auditing standards should be replaced by formal representations in order to provide near-real-time assurance. To be certain, formal 
object-to-object protocols, technological abilities, and objective roles of interconnected objects will rule the Industry 4.0 world.

\subsection{Principle}

Interoperability, Virtualization, Decentralization, Real-Time Capabilities, Service Orientation, and Modularity are the six main technical principles of Industry 4.0. Audit 4.0, like Industry 4.0 , is based on these six principles to improve data accessibility, encourage easier data monitoring and verification, and promote audit procedure automation.

Interoperability is a significant design concept for the future lifestyle and an important driver of Industry 4.0. Field devices, machines, factories, factories, and even products will all be connected and interact over a global network in Industry 4.0 [20], allowing for interoperability within and beyond the value chain. The new business model can become more intelligent and informative through communication and interoperability, resulting in a better level of optimization. Interoperability may have a greater impact on the auditing profession as it continues to transform business structures. Interoperability between suppliers, customers, banks, and other business organizations can enable near-real-time scrutiny of transaction-level events and completion claims in Audit 4.0. Secure networks are built to make it easier for different business organizations to communicate with one another. The two ERP systems will share associated accounting information in a transaction involving two business entities. Entities will get the data, compare it to the necessary data in their system, and send a warning if the matches are not possible. Such collaborations can automate transaction analysis and alert auditors and management to suspect transactions.

Virtualization. When items are connected to a network in Industry 4.0, data about their locations, conditions, surrounding environment, and other factors may be exchanged and integrated. The data can be searched, explored, and analyzed [20]. Using this data, a virtual replica of the physical world may be produced, reflecting all of the business's objects, their interactions, and actions. In this universe, every physical "object" has a digital representation with such a unique code (for example, a business entity's legal entity identifier), and the data is constantly updated and transferred to the appropriate parties. Virtualization allows for complete transparency throughout the value chain, with all business activities and their results displayed in particular [21]. Through virtual process monitoring, management may spot problems and inefficiencies in real-time. Virtual reproduction and simulation will also aid $\mathrm{R} \& \mathrm{D}$ in detecting and removing new product defects [21].

Decentralization. Cloud systems with virtual machines are heavily used in enterprise information technology. Soon, the capabilities of today's radio frequency recognition (RFID) chips will be replaced by standalone computers that perform a huge number of increased functions, extending these systems to ever larger and more intelligent network "things." The manufacturing system is becoming more complicated as the demand for customized items grows, making it difficult to control machinery from a single location [22]. For example, more than 15 billion possible Ford Fusion configurations are available on the German market [23]. For example, there are about 15 billion potential Ford Fusion configurations [22]. Because of the high demand for customization, production operations and assembly lines must be decentralized, allowing each machine or production line to make its judgments and modifications [21]. Decentralization will expand to the auditing profession as the business environment grows more complicated and dynamic. Internal control mechanisms that continuously monitor accounting data and detect anomalous transactions that exceed the expected threshold can be implemented in any equipment or device. These systems will 
update their thresholds in response to changes in the environment and auditor input and report complicated failures and conclusions to the auditor for further review. This system will become a significant improvement to the current audit process [24].

Real-Time Capabilities. Industry 4.0 factories continuously monitor the condition of physical items and manufacturing processes in order to detect system problems, alter production, and make real-time choices. If a machine malfunction is identified, the firm will react quickly and move production to another machine [25]. Long-term, factories will respond in real-time to changing market demands, technology choices, and laws [26]. Vasarhelyi, Halper, and Ezawa [24] propose an "audit with exceptions," in which measurements analyze the system, standards serve as benchmarks, and analytics incorporate rules for generating warnings that initiate the real audit. Siemens Corporation created and implemented a costeffective methodology for real-time control monitoring [27]. This model examines control settings and detects elevated transactions that surpass predicted limits and parameters in actual time. Kim and Vasarhelyi [28] developed a methodology to identify fraudulent wire transfer online payment transactions. The model may detect probable fraud quickly and alert the auditor to further inquiry by assessing each transaction against specified fraud indicators and estimating the overall fraud risk.

Service orientation. Bucker et al. [22] define Industry 4.0's service-oriented qualities as follows: "IoS provides access to enterprise, CPS, and human services, which other users can use. This business strategy, particularly in industries with a growing demand for bespoke products, can drastically lower manufacturing costs and generate additional profits by enhancing stakeholder participation. Audit 4.0 can use a service-oriented design to make it easier for auditors and other relevant service providers to collaborate. Data analysis, for instance, is a popular and efficient technology that the auditing profession recognizes, but its use falls short of expectations [17]. Auditors might spare themselves from analytical work and focus on crucial judgments by enlisting the help of professionals. In a similar line, cloud-based audit software services are available.

Modularity. In Industry 4.0, modular systems have an advantage since they can easily adapt to changing conditions or requirements [22]. This model is adaptable to seasonal swings and can develop new configurations [22]. Byrnes et al. [5] modularity can let auditors perform analyses more flexibly and efficiently. They propose using an audit application as a module and combining it with other modules to fully analyze. A set of rigorous analytical routines conducted by computerized instruments is an audit application [5]. Typically, each audit application runs one analytics-based audit test. Auditors can use customized audit plans to identify and deploy appropriate audit applications and audit with exceptions. For each audit client, a different collection of apps is selected and installed sensitive to individual risks, client capabilities, business environment, and auditor qualifications.

\subsection{Technology}

Industry 4.0 and Audit 4.0 enterprise intelligence, flexibility, interconnection, and enterprise are enabled by sensors, CPS, IoT, IoS, and smart factories. RFID, GPS, and data analytics are some of the other technologies that can be used to enhance next-generation audits.

Sensors. Low-cost, low-power, multifunctional sensors were made practical by advances in micro-electro-mechanical systems and digital electronics at the dawn of the twenty-first century [29]. These sensors, which have data collecting, processing, and transmission features, will be widely employed in Industry 4.0 and will replace humans in data collection. 
Pacemakers, position identifiers (e.g., GPS), and individual identifying devices (e.g., RFID tags) are examples of sensors [30]. Smart homes, smart industries, and smart cities can benefit from applications that use sensor data and spatial information [31].

Accounting data is becoming increasingly automated [32]. Sensors can acquire data at a near-real-time rate and with a significantly broader range of data. Sensors incorporated into the manufacturing system, logistics system, or product are effective approaches to acquire accounting data. The use of devices and equipment embedded into a manufacturing or service system for audit purposes is defined as support by Appelbaum, Kogan, and Vasarhelyi [33]. Auditors can acquire real-time accounting information that represents current performance, such as stock quantity and quality, worker hours worked, energy usage, and so on, using this technique, and identify system faults in real time.

Cyber-Physical System (CPS). The Cyber-Physical System is another piece of technology that will be crucial in Audit 4.0. (CPS). Computers, sensors, and actuators are all combined onto one platform in this revolutionary technology. CPS connects the physical and digital worlds by monitoring and documenting the physical production process, evaluating data, and creating integrated virtual models that link with other CPSs to allow real-time monitoring and decision making. Intelligent preventive maintenance [34] is an example of CPS, in which engine sensors gather process characteristics like stress, temperature, working hours, and the based embedded tracks wear. The actual state of the machine can be measured by integrating information from the physical item and its digital process parameters.

CPS can be utilized in the context of Audit 4.0 to monitor and analyze accounting data flow, recognize behavioral trends in various business sectors, identify deviations or abnormalities, and take appropriate action. Because future machines, gadgets, and products will be equipped with CPS, they will automatically activate enterprise ERP systems to record accounting transactions and business events without the need for human interaction. Furthermore, because CPS saves a history of business activity and the movement and condition of material things, the data can verify the company's financial data. Auditors and management can receive real-time notifications if transaction records violate accounting rules by automating comparisons between information contained in CPS and comparable accounting data in enterprise ERP systems.

The Internet of Things (IoT) is a vital component that allows factories to advance into new industrial generations. IoT is a paradigm in which physical items are embedded with RFID tags, sensors, or CPS and connected to a network that allows devices, systems, and people to communicate [25], [30]. The basic purpose of IoT infrastructure is to connect everything in the world of business into a network so that it can share information about its state, environment, manufacturing processes, and maintenance plans [25], [35]. This infrastructure gathers and distributes data throughout the value chain, allowing for real-time decision-making and business automation.

Auditors can use the IoT infrastructure to provide comprehensive real-time assurance. When monitoring and auditing transaction information, recent studies advocate the use of a considerably broader range of data, i.e., big data, than previously specified accounting data [18], [33], [36]. Blogs, discussion boards, and social media, for example, can be used to evaluate financial data [30]. Evidence in photos, videos, and GPS coordinates can also be used to validate transactions [36]. IoT technology can let auditors acquire high-volume, heterogeneous data structures from a variety of sources in real-time. IoT can also help with real-time cost and performance monitoring of corporate processes. Companies can use IoT to remotely monitor the energy use of individual machines and industrial lines, for example [25]. 
By comparing production plans with real-time energy consumption, internal auditors can uncover inefficient energy use.

Internet Service. People can now get computing resources, electronic storage, and even expert knowledge via the internet, thanks to the increasing digitalization of services. The major goal of IoS is to give businesses a platform on which they may provide remote services to a variety of clients. The THESEUS project [37] is a great example of IoS. THESEUS is concerned with network technologies that make it easier and more precise to find, combine, use, and pay for services. It also aims to create a fully open cloud platform for developers and market participants to create new apps, services, and business models [38]. The platform improves service availability transparency, simplifies collaboration across diverse partners, and allows participants to create web-based services.

An inspection of an organization's financial statements is provided by auditing, which is a service business. With the advancement of ERP system technology and the digitalization of accounting data, this profession is gradually moving into online digitization services. Vasarhelyi, Halper, and Ezawa [24] suggested a new audit model that updates and analyzes an organization's accounting data flow. Abnormalities or exceptions will set off alarms, drawing the attention of auditors. This continuous auditing and monitoring can be viewed as an online service that audit firms can provide to clients remotely, continuously, and possibly automatically. The company will submit a request for services over the internet, and the demand will be matched with the audit firm's capabilities. To evaluate account data running through the organization, audit firms will implement their continuous auditing and monitoring model using cloud-based infrastructure or the company's accounting information systems.

Smart factory and intelligent products. The fourth industrial revolution ushers advance in sensors, CPS, IoT, and IoS, fostering a new intelligent, flexible, and secure factory: the "smart factory." Bucker et al. [22] explained that intelligent factories will embrace an entirely new production method, with innovative goods identifiable and traceable and self-awareness and optimization capabilities. The entire production system is linked horizontally with associated parties outside the factory and vertically with other business operations.

Data processing, storage, and analysis operations are integrated with smart factories, resulting in smart goods. To aid quality control and product creation, smart products record and transmit their condition and status and customer behavior and demands to the manufacturer. Smart factories can also communicate with suppliers to ensure that inventory is replenished on time compared to typical manufacturing [25]. Smart factories are thus at the center of Industry 4.0. Auditors can use the data and functionality that smart factories collect and integrate across the value chain to monitor and control accounting data flow within an organization, share financial data among related parties, perform preventive and predictive audits, and accomplish near-real-time assurance, expand a business.

Several existing audit procedures, such as inventory valuation and measurement using smart product location and condition tracking, and automatic validation of transactions using suitable accounting records from associated parties, can be automated in the context of a smart factory. Furthermore, auditors may now evaluate increasingly huge volumes of data from a variety of sources to offer exact "predictive assurance" data" [39]. Another strategy that aids in the implementation of Audit 4.0. In the virtual world, RFID can identify items and provide product status. Products can be tracked using GPS. Furthermore, smart ID cards can be used to track company employees' position to offer them on-site guidance and instructions [40]. By discovering patterns, detecting abnormalities, identifying linkages, and getting other useful audit-related information, data analytics will remain to play an essential role in Audit 4.0. 


\subsection{Auditor}

The skills of auditors must shift considerably in a world of intense automation and process control. This necessity is discussed by Appelbaum, Kogan, and Vasarhelyi [41]. Auditors should be more technologically trained, but processes should be designed with untrained users in mind as well. For example, to support the auditor's use of clustering, Byrnes et al. [5] built a "super app." Not only does this tool do grouping, but it also applies statistical expertise to supplement the auditor's knowledge.

\subsection{Imagineering AUDIT 4.0}

The business world moves toward a highly automated, highly flexible, highly interconnected, and highly interconnected environment. Real-time enterprise fault detection, prediction, and decision-making capabilities result from the widespread use of sensors, CPS, IoT/iOS, and intelligent factories. The auditing profession must move with the times and take advantage of new technology to broaden the scope of audits, reduce time, improve accuracy, and, eventually, boost the level of confidence in the business sector. This section considers how auditing might alter in the coming Audit 4.0 world.

Because Robotic Process Automation (RPA) has the potential to alter the auditing profession and the role of auditors by automating repetitive work and focusing on higher-order thinking skills, it's critical to have a strategy in place to enable a smooth transition [42], [43]. In essence, the auditor's job will shift from that of a data collector, processor, analyzer, and disseminator to one that focuses on the audit procedure system's evaluation component. However, while creating an RPA for an audit, various factors must be addressed, including: Which auditing processes should be automated first?

1. How to filter the auditing process to some small steps that are suitable for automatization?

2. What are the possible outcomes of audit procedures if they are automated?

3. What is the data format that is readable by machine?

4. Which audit procedures should be targeted for automation based on the previous stage's assessments?

5. Does the RPA perform as expected during the prototype phase?

6. Can areas for improvement be discovered through review and feedback?

\subsection{Indonesia's current state of internal government auditors}

APIP's responsibilities as the government's internal auditor are now increasingly vital and significant due to industry 4.0, affecting the system and dynamics of audit activity [44]. This is where APIP must again prepare and adapt to Industry 4.0, which impacts APIP's audit activities. APIP must continue to carry out its functions effectively amidst the challenges and risks in this disruptive era [44]. The quality of internal auditors can be seen, one of which is in terms of capabilities. The Institute of Internal Auditors (IIA) has developed the Internal Audit Capability Model (IACM) [13]. The spirit of auditor 4.0 has been accommodated by IACM in KPA element I: Roles and Services, namely:

1. Level 4 "APIP provides comprehensive assurance on governance, risk management, and organizational control." The assessment indicators are: "Has the internal audit activity utilized the enabling technology in conducting audits and analysis to help assure independence on the effectiveness of governance, risk management, and internal control processes." 
2. Level 5 "Internal auditors are recognized as key agents of change." The assessment indicators are: "Does the internal audit activity use industry-leading practices and technology and innovative approaches to internal auditing to improve its work and provide greater value to the organization."

KPA in element I above talk about supporting facilities and infrastructure in creating Auditor 4.0, while on the side of increasing HR capabilities to form auditors who have the skills and personalities required as mentioned above, IACM has also been accommodated with Element II "HR Management." This element consists of 10 KPAs and KPAs that are directly related to human resource capacity building, namely:

1. Level 4, "APIP supports professional organizations" with assessment indicators including:

a) APIP has supported outstanding employees in the organization in terms of time, financial and other resources, and for this support, criteria, and mechanisms have been set.

b) APIP has encouraged employees who are actively involved in a professional organization to contribute and develop their careers.

2. Level 5, "APIP leaders and internal auditors are actively involved in the core management of professional organizations" with assessment indicators including:

a) APIP has learned from other APIPs and has integrated practices and thinking that are strategic and relevant to the organization.

b) APIP is involved in an organization, and this involvement has spurred APIP to learn and improve his knowledge and thinking.

The IACM, with its KPAs mentioned above, is only an instrument supporting organizations informing their auditors into 4.0 auditors. The role of the organization/management will determine the success of these targets. So it takes management that is committed and synergized between departments. The biggest obstacle that an organization often faces is coordination, so that programs or activities that a section has prepared may not necessarily run. Because they are not coordinated to the budget section so that the budget is not available or is not coordinated with the activity planning section, there is no time allocation to implement them [45].

In the scope of APIP agencies throughout Jambi Province, the supervision process by auditors and data readiness by auditees has not reached audit level 4.0. This can be seen in the APIP capability assessment, and SPIP maturity[14] was for the 12 local governments in Jambi Province. There has not been a single local government that has reached level 4 for both the APIP capability assessment results and the SPIP maturity assessment results. Currently, the audit process is still at audit level 2.0, with the Excel application as the main data processing application. Even the application of CAAT (computer-assisted audit techniques) software has not been implemented.

\subsection{APIP's Transformation Strategy in the 4.0 Industrial Revolution Era}

Internal auditors must have the appropriate strategy to deal with the many changes that occur for the auditor's role to be effective [46]. Dai and Vasarhelyi [16] stated that there are several strategies for internal auditors in facing the challenges that will be posted in the industrial era 4.0, namely:

1. APIP must be able to collect data using tools such as sensors and software. APIP may thus provide enterprises with comprehensive assurance by gathering and examining business processes in real-time to detect violations. 
2. APIP must have a character that becomes his trademark in completing his audit task. These characters include cognitive abilities, the ability to solve complex problems, communication skills, understanding of their position in the internal control system, and agility. Cognitive ability is related to the ability to understand, analyze, and assess a problem. Auditors with good cognitive abilities can identify problems correctly, cause and effect, and their solutions so that the recommendations given are right on target. They can overcome the root of the problem and prevent these errors from happening again in the future. APIP is also required to be able to communicate well with his work environment. By applying communication skills, audits can be carried out effectively and efficiently, especially in obtaining data and information, coordinating activities within the audit team, improving audit quality, and improving the image of the internal auditors. An understanding of the duties and functions of an auditor in the internal control system is a guide for an auditor in carrying out their duties considering the objectives, methods, and results to be achieved in each type of assignment are different. However, globally, APIP's job is as an assurance provider and consultant. This understanding must be supported by good agility so that an APIP can work dynamically and quickly adapt to changes that may occur during the assignment.

3. APIP must be professional, millennial, innovative, and not afraid of failure while still prioritizing integrity, objectivity, and professionalism. The development of technology is an opportunity to innovate in supervision by developing a monitoring planning system for reporting. Existing systems must continue to be built and refined. Existing innovations must provide added value to the organization and be inclusive, which means providing benefits to partners in improving performance and control, reducing activity risks, and ultimately supporting the realization of organizational goals.

Education and training in the development and use of information technology have a vital role in providing supplementary skills for APIP. Such education and training are very much needed to ensure that the competence of auditors is relevant to the development of the digitalbased era. Thus, the auditor will be required to master the techniques, principles, and knowledge of procedures regarding auditing using information technology. Auditors must have data and technology literacy to take advantage of opportunities and face challenges in the 4.0 industrial revolution. This data literacy is needed to improve APIP's ability to process data and analyze big data to increase monitoring services. Technology literacy shows the auditor's capability to utilize digital technology for data and information processing. If this process has been carried out properly, then APIP will not be technologically savvy and will answer challenges and face the Industrial Revolution 4.0 [45].

\section{Conclusion}

From the results of the research and discussion above, it can be concluded that some of the challenges faced in the industrial era 4.0, such as the problem of information technology security, lack of adequate skills, inability to adapt, resistance, and the loss of several jobs due to automation. Considering the challenges faced in the Industrial Revolution 4.0 era, a transformation strategy is needed for APIP to survive in this era. Strategies that APIP can carry out in facing the challenges of industry 4.0 include: (1) APIP must be able to use datacollecting equipment such as sensors and software, (2) APIP must have characters that become his trademark in completing his audit tasks and (3) APIP must be professional, 
millennial, innovative and not afraid of failure while still prioritizing integrity, objectivity, and professionalism.

\section{References}

[1] K. Schwab, The Fourth Industrial Revolution. World Economic Forum, 2016.

[2] WEF, The Future of Jobs Report 2018, vol. 31, no. 2. 2018.

[3] Peraturan Pemerintah Nomor 60 Tahun 2008, Sistem Pengendalian Intern Pemerintah, no. May. Indonesia, 2008.

[4] C. Karlsen, "The effects of digitalization on auditors' tools and working methods," University Of Gavle, 2012.

[5] P. E. Byrnes et al., "Evolution of Auditing: From the Traditional Approach to the Future Audit," Contin. Audit., pp. 285-297, 2018, doi: 10.1108/978-1-78743-413420181014.

[6] Forbes Insight, “Audit 2020: A Focus On Change,” 2015 Forbes Insights, p. 16, 2015, [Online]. Available: https://images.forbes.com/forbesinsights/StudyPDFs/KPMGAFocusOnChange-REPORT.pdf.

[7] D. R. Lombardi, R. Bloch, and M. A. Vasarhelyi, "The current state and future of the audit profession," Curr. Issues audit., vol. 9, no. 1, pp. P10-P16, 2015, doi: 10.2308/ciia-50988.

[8] G. Spraakman, W. O'Grady, D. Askarany, and C. Akroyd, "Employers' Perceptions of Information Technology Competency Requirements for Management Accounting Graduates," Account. Educ., vol. 24, no. 5, pp. 403-422, 2015, doi: 10.1080/09639284.2015.1089177.

[9] Kementerian Keuangan, "Peran APIP dalam Mewujudkan Tata Kelola Pemerintahan yang Bersih," 2015.

[10] The Institute of Internal Auditors, "Global Perspectives and Insights : Internal Audit in the Age of Distruption," pp. 1-5, 2018.

[11] IAI, "Menguasai Perubahan, Menyiapkan Masa Depan," Prakarsa 6.1, pp. 1-65, 2019, [Online]. Available: http://www.iaiglobal.or.id/v03/berita-kegiatan/detailberita-1128program-prakarsa-61-meneguhkan-kejayaan-akuntan-profesional.

[12] Peraturan Presiden Nomor 2, Rencana Pembangunan Jangka Menengah Nasional 2015-2019, vol. 114, no. 1. 2015, pp. 2015-2019.

[13] The Institute of Internal Auditor, Internal Audit Capability Model (IACM) for The Public Sector. 2009.

[14] BPKP, "Laporan Kinerja Tahun 2019," 2019.

[15] S. Rahayu, S. Yudi, and S. Rahayu, "Internal auditors role indicators and their support of good governance," Cogent Bus. Manag., vol. 7, no. 1, 2020, doi: $10.1080 / 23311975.2020 .1751020$.

[16] J. Dai and M. A. Vasarhelyi, "Imagineering audit 4.0," J. Emerg. Technol. Account., vol. 13, no. 1, pp. 1-15, 2016, doi: 10.2308/jeta-10494.

[17] Q. Liu and M. A. Vasarhelyi, "Big questions in AIS research: Measurement, information processing, data analysis, and reporting," J. Inf. Syst., vol. 28, no. 1, pp. 117, 2014, doi: 10.2308/isys-10395.

[18] H. Brown-Liburd and M. A. Vasarhelyi, "Big Data and Audit Evidence," J. Emerg. Technol. Account., vol. 12, no. 1, pp. 1-16, 2015, doi: 10.2308/jeta-10468.

[19] M. A. Vasarhelyi, D. Y. Chan, and J. P. Krahel, "Consequences of XBRL 
standardization on financial statement data," J. Inf. Syst., vol. 26, no. 1, pp. 155-167, 2012, doi: 10.2308 /isys-10258.

[20] R. Drath and A. Horch, "Industrie 4.0: Hit or hype? [Industry Forum]," IEEE Ind. Electron. Mag., vol. 8, no. 2, pp. 56-58, 2014, doi: 10.1109/MIE.2014.2312079.

[21] G. Schuh, T. Potente, C. Wesch-Potente, A. R. Weber, and J. P. Prote, "Collaboration mechanisms to increase productivity in the context of industrie 4.0," Procedia CIRP, vol. 19, no. C, pp. 51-56, 2014, doi: 10.1016/j.procir.2014.05.016.

[22] I. Bucker, M. Hermann, T. Pentek, and B. Otto, "Towards a Methodology for Industrie 4.0 Transformation," Lect. Notes Bus. Inf. Process., vol. 255, p. VI, 2016, doi: 10.1007/978-3-319-39426-8.

[23] H. Schleich, J. Schaffer, and L. F. Scavarda, "Managing complexity in automotive production," 19th Int. Conf. Prod. Res., pp. 1-6, 2003, [Online]. Available: $\mathrm{http} / /$ citeseerx.ist.psu.edu/viewdoc/download?doi=10.1.1.386.4852\&rep=rep1\&type=p df.

[24] M. A. Vasarhelyi, F. B. Halper, and K. J. Ezawa, "The Continuous Process Audit System: a UNIX-based auditing tool," EDP Auditor Journal, vol. 3, no. 3. pp. 85-91, 1991 , [Online]. Available: http://proxy.lib.siu.edu/login?url=http://search.ebscohost.com/login.aspx?direct=true\& $\mathrm{db}=$ inh \&AN $=4104442 \&$ site $=$ ehost-live $\&$ scope $=$ site .

[25] F. Shrouf, J. Ordieres, and G. Miragliotta, "Smart factories in Industry 4.0: A review of the concept and of energy management approached in production based on the Internet of Things paradigm," IEEE Int. Conf. Ind. Eng. Eng. Manag., vol. 2015-Janua, pp. 697-701, 2014, doi: 10.1109/IEEM.2014.7058728.

[26] D. Anwendung et al., "Industrie 4.0 in Produktion, Automatisierung und Logistik," Ind. 4.0 Produktion, Autom. und Logistik, pp. 3-4, 2014, doi: 10.1007/978-3-65804682-8.

[27] M. Alles, G. Brennan, A. Kogan, and M. A. Vasarhelyi, "Continuous monitoring of business process controls: A pilot implementation of a continuous auditing system at Siemens," Int. J. Account. Inf. Syst., vol. 7, no. 2, pp. 137-161, 2006, doi: 10.1016/j.accinf.2005.10.004.

[28] Y. Kim and M. A. Vasarhelyi, "A model to detect potentially fraudulent/abnormal wires of an insurance company: An unsupervised rule-based approach," J. Emerg. Technol. Account., vol. 9, no. 1, pp. 95-110, 2012, doi: 10.2308/jeta-50411.

[29] I. F. Akyildiz, W. Su, Y. Sankarasubramaniam, and E. Cayirci, "A Survey on Sensor Network," IEEE Communications Magazine, vol. 15, no. August, pp. 213-223, 2002.

[30] D. E. O'Leary, “Artificial Intelligence and Big Data," IEEE Intell. Syst., vol. 28, no. 2, pp. 96-99, 2013, doi: 10.1109/MIS.2013.39.

[31] V. Paelke, "Augmented Reality in The Smart Factory: Supporting Workers in an Industry 4.0. Environment," 19th IEEE Int. Conf. Emerg. Technol. Fact. Autom. ETFA 2014, 2014, doi: 10.1109/ETFA.2014.7005252.

[32] M. Jans, M. Alles, and M. Vasarhelyi, "The case for process mining in auditing: Sources of value added and areas of application," Int. J. Account. Inf. Syst., vol. 14, no. 1, pp. 1-20, 2013, doi: 10.1016/j.accinf.2012.06.015.

[33] D. Appelbaum, A. Kogan, and M. Vasarhelyi, "Moving towards continuous audit and big data with audit analytics: Implications for research and practice," pp. 1-82, 2015.

[34] H. Lasi, P. Fettke, H. G. Kemper, T. Feld, and M. Hoffmann, "Industry 4.0," Bus. Inf. Syst. Eng., vol. 6, no. 4, pp. 239-242, 2014, doi: 10.1007/s12599-014-0334-4.

[35] Marcos A. Pisching, Fabricio Junqueira, Diolino J. dos Santos Filho, and Paulo E. 
Miyagi, "an Architecture for Organizing and Locating Services To the Industry 4.0," Proc. 23rd ABCM Int. Congr. Mech. Eng., no. January 2016, pp. 0-8, 2015, doi: 10.20906/cps/cob-2015-0415.

[36] K. C. Moffitt and M. A. Vasarhelyi, "AIS in an age of big data," J. Inf. Syst., vol. 27, no. 2, pp. 1-19, 2013, doi: 10.2308/isys-10372.

[37] K. Buxmann, P. Kistler, and G. Rebitzer, "Independent Information Modules-a Powerful Approach for Life Cycle Management," Int. J. Life Cycle Assess., vol. 14, no. SUPPL. 1, pp. 92-100, 2009, doi: 10.1007/s11367-009-0075-7.

[38] H. Kagermann, "Change Through Digitization - Value Creation in the Age of Industry 4.0," Manag. Perm. Chang., pp. 1-240, 2015, doi: 10.1007/978-3-658-05014-6.

[39] S. Kuenkaikaew and M. A. Vasarhelyi, "The predictive audit framework," Int. J. Digit. Account. Res., vol. 13, no. May, pp. 37-71, 2013, doi: 10.4192/1577-8517-v13_2.

[40] D. Gorecky, M. Schmitt, M. Loskyll, and D. Zühlke, "Human-machine-interaction in the industry 4.0 era," Proc. - 2014 12th IEEE Int. Conf. Ind. Informatics, INDIN 2014, pp. 289-294, 2014, doi: 10.1109/INDIN.2014.6945523.

[41] D. Appelbaum, A. Kogan, and M. A. Vasarhelyi, "Big data and analytics in the modern audit engagement: Research needs," auditing, vol. 36, no. 4, pp. 1-27, 2017, doi: 10.2308/ajpt-51684.

[42] L. Willcocks, M. Lacity, and A. Craig, "The IT Function and Robotic Process Automation," Proj. Manag. Plan. Control, no. October 2015, pp. 372-380, 2015, doi: 10.1016/b978-075066956-6/50051-4.

[43] S. Seasongood, "A Case fo Robotics in Accounting and Finance," 2016.

[44] Daryanto, "Antisipasi Perubahan Peran Auditor Pemerintah dalam Menghadapi Revolusi 4.0," Warta Pengawasan, 2019.

[45] H. Subkie and N. Hasanah, “APIP Bersiap Menyongsong Era Indusrial 4.0,” Media Auditor, vol. 50, 2019.

[46] Rahayu and S. Rahayu, "The Role of Internal Auditor Government to Realize The Clean Local Government," Malaysia Indones. Int. Conf. Econ. Manag. Account., no. October, p. 761, 2016, [Online]. Available: https://repository.unja.ac.id/166/1/MIICEMA_proceeding_2016.pdf. 